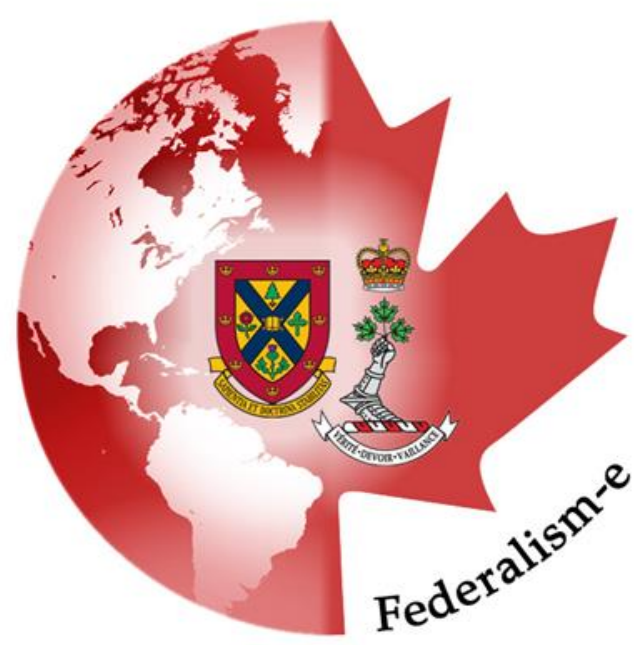

\title{
Compulsory Voting, Identity, and Nation Building- The Importance of the Compulsory Vote
}

\section{JOEL HOLDAWAY \\ University of Victoria}

One hundred twenty five euros. This is the fine that Belgian citizens are liable for if they abstain from voting more than once in a national election. ${ }^{1}$ Not surprisingly, voter turnout in Belgium is one of the highest in the world and amongst the top three in industrialized liberal democracies. Between 1978 and 1999, the average voter turnout for registered voters in Belgium was ninety-three percent and the average turnout for those of voting age was eighty-seven percent. $^{2}$ This marks a clear departure from regimes such as France, wherein the registered voter turnout for the legislative elections during the same period was seventyone percent. ${ }^{3}$ Though one may note that the

\footnotetext{
${ }^{1}$ United Kingdom, Parliament, "The Electoral Commission," Compulsory voting around the world Research report, 2006.

2 Jonathon Louth and Lisa Hill, "Compulsory Voting in Australia: Turnout with and without it," Australian Review of Public Affairs 6, no. 1 (2005): 32.

${ }^{3}$ International Institute for Democracy and Electoral Assistance, "Voter Turnout Data for France (Parliamentary, Presidential, EU Parliament),"
}

turnouts for registered voters in France and Belgium are within fourteen percentage points of one another, the unfortunate reality that the majority of those fourteen percentage points represent the lower socio-economic demographic inspires concern. ${ }^{4}$ Moving to the supranational level of the European Parliament, voter turnout is even lower. The most recent election (in 2009) motivated forty-three percent of voters to visit the polls. ${ }^{5}$ When the influence that these elected institutions have on public policy is considered, this number is troubling. If one were to evaluate how public policy decisions affect identity and nationalism, there is even more reason to be concerned. Thus, not surprisingly, there are a number of proposed methods, discussed by scholars and politicians alike, as to how to increase voter turnout.

\footnotetext{
http://www.idea.int/vt/countryview.cfm?id=53 (accessed 10 November 2012)

${ }^{4}$ Louth and Hill, "Compulsory Voting in Australia:

Turnout with and without it," 26-27.

${ }^{5}$ European Commission, "Voter Turnout in National and EU Parliamentary Elections," Eurostat.

http://epp.eurostat.ec.europa.eu/portal/page/portal/ product_details/dataset?p_product_code=TSDGO310 (accessed 8 November 2012)
} 
With Europe's history of government restriction of electoral lists, compulsory voting is not only socially responsible, but would greatly reduce the democratic deficit and prevent governments from limiting certain duties, rights and freedoms of citizenship. Where the current situation in European nations has mainly intellectuals and those of greater socio-economic standing supportive of the EU, compulsory voting at the Union level would also help to foster a sense of identity and potentially bring together individuals across all socio-economic backgrounds. $^{6}$

This paper will address the complex relationship between voting, policy formation, identity formation, and nationalistic tendencies, allowing a subsequent prediction of how an ideal European Union might operate if compulsory voting was implemented at the national and supranational levels. This will be done first by breaking down the reasons (and misconceptions) behind identity formation and nation building, and then by describing the closed feedback loop that exists between voting and nationalism. Next, this paper will analyze the benefits of compulsory voting in the member states via a case study of France. Finally, this paper will speculate about how Europe might look if compulsory voting was implemented for the European Parliament, and the possible benefits that this offers not just to the Union's majority groups, but also to cross-border minority nations such as the Romani people.

Because this paper's analysis rests on a certain conception of the term nation, a brief overview of the term is essential. Several scholars have discussed nationalism and perhaps the most widely held description of a nation is Benedict Anderson's idea of nations as imagined

${ }^{6}$ Jean-Yves Dormagen and Daniel Mouchard, Introduction à la sociology politique, (Brussels: De Boeck Supérieur, 2008). communities. ${ }^{7}$ Beyond the idea of nations as imagined communities, one major distinction between types of nations that is frequently discussed is Michael Ignatieff's (1994) differentiation between civic and ethnic nationalism. Ignatieff argues that civic nationalism is based upon citizenship. In other words, one describes her nationality based on which citizenship she holds and thus references the common protections and rights, and a shared set of political practices that exist amongst those who share that citizenship. This definition has its roots in the idea of the civic nation-state, where a nation is distinct from other nations because it has unique rights of self-government. Ethnic nationalism, on the other hand, is based on ethnicity, which consists of a shared set of one or more characteristics (for example, language, culture, ancestry, history, or religion). In this case, citizenship may or may not represent nationality as political rights do not define a nation. One thing that is common to both definitions, however, is loyalty and a sense of belonging to a set of common experiences (whether those experiences are of a set of institutions, or a shared history, language, and culture).

When looking at these distinctions in the context of the European Union, civic nationalism is not representative of reality, as this would mean that the EU is already a nation. Citizens have shared political rights, a shared set of institutions, and they have "European Union" printed above the member state designation on their passports. This, however, does not mean that they see themselves as part of an overarching nation. Common experiences of religion, history, and culture continue to limit a European's allegiance to that of her home country.

Even if one disagrees that the EU currently has enough shared civic institutions to define itself as a nation, Ignatieff's two kinds of nationalism (civic and ethnic) continues to

\footnotetext{
${ }^{7}$ Benedict Anderson, Imagined Communities: Reflections on the Origin and Spread of Nationalism, (New York: Verso, 2006).
} 
present a barrier to positive European integration. This happens because one is faced with a dilemma. From a purely ethnic nationalist perspective, Europe consists of several nations that should cleave to their own independent nation-states. From a civic nationalist perspective, the current situation in Europe is unfavourable when one considers how successful civic nations (such as Canada or the United States) came into being. On the one hand, an evaluation of Canadian history reveals that citizens originally approached nationalism from an ethnic perspective but were forced into a union by an imperial power. The creation of the United States, on the other hand, reveals that union occurred due to the external threat of being conquered. In neither situation did union occur by citizens voluntarily placing their trust in shared institutions. Though European integration began with the European Coal and Steel Community, due to the need for a strong Europe to stand against the threat of Soviet expansionism, it is difficult to provide a convincing argument that Europe must further integrate in order to ensure its survival. Thus, continued integration, where a central government obtains more power, is only possible if citizens see themselves as part of a larger entity and trust fellow constituents of this entity. Since democratic change occurs through the will of the people, nation-building must begin with citizen participation in a shared experience. Compulsory voting could assist citizens in realizing this reality through greater and more equal participation in the Union.

There are an infinite number of ways in which individuals may have common experiences, and each common experience may influence individuals to different degrees. In industrialized liberal democracies (such as those found in Europe today), state institutions are the primary means through which citizens share common experiences. Take, for example, a commune in France. With the exception of the relatively small number of personal relationships that individuals have with one another, residents are connected to their fellow citizens via their employment, media sources, laws and regulations, and public policy initiatives. All citizens are subject to laws as well as influenced by regulations enacted by the state and evidence shows that nearly half of individuals are either directly or indirectly influenced by the state. ${ }^{8}$ In this case, even the most basic interactions with one's employer are influenced by government policy. The fact that every citizen has a relationship with the government, and that most actions taken by the government affect more than one individual, demonstrate the daily, common, state-mediated experiences of citizens. In liberal democratic regimes, these policy initiatives begin and end with the elected bodies that citizens influence through voting. Thus, nation-building occurs because individuals are subject to common experience. If certain residents are excluded from the franchise, public policy (as a common experience that everyone in society faces) is less representative of the general population. It is therefore necessary to have universal suffrage and for elected persons to represent all demographics as equally as possible.

In researching regimes that changed from compulsory to voluntary voting, Jonathan Louth and Lisa Hill (2005) found that "an immediate consequence was an increased variation between subgroups." ${ }^{\prime 9}$ Though compulsory voting is not the only means to ensure equal representation from all demographics or subgroups, it is certainly a "more than satisfactory solution to the problem of low and socially unequal turnout." ${ }^{10}$ Traditional tensions of ethnic nationalism in France have resulted in large sub-groups tending not to have citizenship or in them residing in the lowest socio-economic status. The fact that they are not enfranchised and that they are not required to vote (and tend not to vote in the

\footnotetext{
${ }^{8}$ Rand Dyck, Canadian Politics: Critical Approaches, (Toronto: Nelson Education Ltd, 2011), 257.

${ }^{9}$ Louth and Hill, "Compulsory Voting in Australia: Turnout with and without it," 27.

10 Ibid.
} 
same numbers as the rest of the population) means that their voices are less likely to be considered in public policy initiatives. This has an effect on common experiences and, accordingly, in the development of national identities. Whether it be national policies on health or immigration, or approaches to substance abuse, policy making will always have an effect on the population subject to the laws, rules and regulations of the state. Take, for instance, the recent controversy in Paris over access to public transit. Due to the high number of crimes committed against travellers going to the airport, elected officials are currently discussing the introduction of express trains that would bypass the less wealthy communities in which these crimes occurred. Though these changes are being debated, imagine that the national government decides to follow through on this proposal. The result would surely not only influence individual common experience, but also effect the actions of individuals throughout the area. Those who live in these suburbs are already marginalized economically, socially, and culturally and would only feel more so while those that ride the train to the airport would be less exposed to the problems experienced in this geographic area. Shared experiences between the two sub-groups are reduced but since government institutions continue to be shared between the two groups, interactions between the two groups would still be necessary. Two outcomes from this transit decision are possible, though neither is ideal. This choice, by French officials, could encourage a nation to become more divided or, worse, it could encourage citizens to feel that they are not even part of the French nation but instead belong to the nation of their home country or a new "immigrant nation" within France. The far-right Front National is a prime example of a group campaigning for the latter, promoting the exclusion of individuals in France that are not part of the perceived French nation.

How would this situation look if
compulsory voting was implemented for
legislative and presidential elections in France? If

it were implemented as well as in Australia, it would ensure such a high turnout rate that any study or examination of voting levels between different demographics would be "virtually irrelevant."11 Compulsory voting would ensure that elected politicians, who direct policy formation, are chosen by the entire population. Whether or not it would change the direction of policy is uncertain, but an evaluation of recent elections in France shows that there is a significant impact on who is elected to office. Consider the presidential election in May of 2007. The second round of voting was a run-off between Nicolas Sarkozy of the centre-right Union pour un Mouvement Populaire (UMP) and the Parti Socialiste (PS) Ségolène Royal. Sarkozy won by less than six percentage points. ${ }^{12}$ The fact that most of those who did not vote were in the lower socio-economic demographic, along with the realities of the two round-system (where Sarkozy made efforts to attract the conservative anti-immigrant vote) may lead one to suggest that the marginalized sub-groups would have voted overwhelmingly for the more socialist party. If this had been the case, public reactions would have been significantly different. Media would have responded differently to the election, likely influencing citizens to vote differently in the legislative elections that followed only one month later. Public policy would have been different, and thus common experiences would have also been different. Though speculation about whether this would have had a positive impact in uniting France under one nation is not directly relevant, one thing remains certain: all demographics would have had a fair and equal opportunity to influence public policy, which in turn would have impacted the common experiences that would

\footnotetext{
${ }^{11}$ Louth and Hill, "Compulsory Voting in Australia: Turnout with and without it," 27.

12 Ministére de L'Intérieur, "Résultats de l'élection présidentielle 2007."

http://www.interieur.gouv.fr/Elections/Lesresultats/Presidentielles/elecresult__presidentielle_2 007/\%28path\%29/presidentielle_2007/FE.html (accessed 14 November 2012)
} 
have influenced nation-building and identity politics in the country. Compulsory voting would reduce not only the democratic deficit, but also the imbalance that is currently present in nationbuilding and identity formation within the state.

Though compulsory voting appears to be an attractive option given its ability to ensure better representation of the people in elected bodies, critics may direct one's attention to the fact that in 1970 the Dutch parliament voted with a large margin (91-15) to repeal its compulsory voting requirement. ${ }^{13}$ This raises questions as to the effectiveness of compulsory voting for the European Parliament or EU member-states. Further research into the Netherlands' subsequent elections, however, reveals that a "drop in turnout followed immediately." ${ }^{14}$ While voter turnout between 1946 and 1967 stood at nearly ninety percent, the Netherlands' four national elections between 1994 and 2003 revealed a turnout of seventyeight percent. ${ }^{15}$ Such decreases in participation cannot be ignored when one considers that they were accompanied by increased variation between national subgroups. The introduction of nationalist parties onto the political scene, such as Geert Wilders' Partij voor de Vrijheid (Party for Freedom), has only served to further marginalize these subgroups via populist rhetoric calling for a Netherlands that is based on ethnic citizenship. Without the requirement to vote, this increase in a serious democratic deficit has likely resulted in large distortions between policymaking and the authentic will of the people, leading to the magnification of ethnic, religious, and economic divisions within Dutch society.

On the supranational level, one group that is marginalized across the entire EU is the Romani people. Without their own nation-state, the Roma constitute a minority in every country in which they reside. Unique cultural practices

\footnotetext{
${ }^{13}$ Louth and Hill, "Compulsory Voting in Australia:

Turnout with and without it," 27.

14 Ibid.

15 Ibid.
}

and values have resulted in discrimination and exclusion for generations. ${ }^{16}$ Since they are spread across several states, the only unifying entity to which a majority of European Roma belong is the central institutions of the EU. In the most recent elections to the European Parliament, however, voter turnout was a shocking forty-three percent. With the European Parliament being the EU's only directly elected institution, such low voter turnout is alarming when one considers that one-hundred percent of Europe's population is subject to the choices made by these institutions. Such low levels of participation not only hinder the development of an overarching European nation (that requires mutual trust between its citizens), but they also severely undermine the one set of institutions that unite nations who stretch across memberstate borders such as the Roma. Compulsory voting could greatly reduce the democratic deficit and enhance the legitimacy of the EU for different subgroups. Additionally, compulsory voting could also encourage individuals from different member-states to join together in exercising their democratic right to select parties that represent pan-European interests. Such participation could not only encourage mutual trust, but would also provide a mechanism of exclusion through which citizens of the EU can share in an activity that non-European citizens could not.

It is essential to recognize that if compulsory voting were implemented at both the national and EU levels, citizens may choose to vote against further European integration. Though this would certainly not be conducive to developing a European identity, nation-building and identity formation must nevertheless begin with the people and proceed through democratic pathways. If it is the will of the people not to form a European identity, compulsory voting

\footnotetext{
${ }^{16}$ National Demographic Institute, "Roma Political Participation Initiative," National Demographic Institute, accessed 10 November, 2012, http://www.ndi.org/roma-political-participationinitiative.
} 
would ensure that this desire is recognized. One may also argue that the ability to consult every citizen, including those of marginalized groups would enhance stability, whereas a European identity built on the will of the elite would be fundamentally unstable.

Coined by Ignatieff in 1994, scholars tend to differentiate between ethnic and civic nationalism. While ethnic nationalism focuses on a common history, culture, language, and religion; civic nationalism focuses on a common set of values, institutions, and rights. One significant element of both definitions, however, is the word common. This paper has argued that nations are formed due to common experience, whether that be gained through a common governmental institution that develops policy, or a common educational curriculum explaining history. Since nations are imagined communities, the most powerful force in uniting people are government institutions and their public policy initiatives. In industrialized liberal democracies such as those of the European Union, these institutions are elected by the general population. Unfortunately, without compulsory voting, turnout amongst certain socio-economic and ethno-cultural groups is significantly lower than others. This results in elected institutions and public policy initiatives that are not representative of the whole of the population. Since these policies and institutions play such a large role in nation-building and identity formation, certain groups are excluded from the process and, by definition, the outcome. In France, this has resulted in further marginalization of already marginalized groups, which assists in legitimizing divisive policies propagated by the far-right Front National. With regards to the European Parliament, poor electoral turnout has resulted in a disconnect with the overarching union and has undermined the only set of institutions that unites transborder nations such as the Romani people. Though compulsory voting is not the only means of reducing the deficits in justice and democracy, it could be a major step forward in ensuring that all members of a state have their voice heard in nation-building and identity formation efforts. 


\section{Bibliography}

Anderson, Benedict R. O'G. Imagined Communities : Reflections on the Origin and Spread of Nationalism. Rev. ed. New York: Verso, 2006.

Dormagen, Jean-Yves and Daniel Mouchard. Introduction à la sociology politique. Brussels: De Boeck Supérieur, 2008.

Dyck, Rand. Canadian Politics: Critical Approaches. Toronto: Nelson Education Ltd, 2011.

European Commission. "Voter Turnout in National and EU Parliamentary Elections." Eurostat. http://epp.eurostat.ec.europa.eu/portal/page/portal/product_details/dataset?p_product_code=TS DGO310 (accessed 8 November 2012)

Ignatieff, Michael. Blood and Belonging : Journeys into the New Nationalism. Toronto: Penguin, 1994.

IDEA. International Institute for Democracy and Electoral Assistance. "Voter Turnout Data for France (Parliamentary, Presidential, EU Parliament)."http://www.idea.int/vt/countryview.cfm?id=53 (accessed 10 November 2012)

Louth, Jonathon, and Lisa Hill. "Compulsory Voting in Australia: Turnout with and without it." Australian Review of Public Affairs 6, no. 1 (2005): 25-37.

Ministére de L'Intérieur. "Résultats de l'élection présidentielle 2007." http://www.interieur.gouv.fr/Elections/Lesresultats/Presidentielles/elecresult_presidentielle_2007/\%28path\%29/presidentielle_2007/FE.ht ml (accessed 14 November 2012)

National Demographic Institute. "Roma Political Participation Initiative." National Demographic Institute, accessed 10 November, 2012, http://www.ndi.org/roma-political-participation-initiative.

New York Times. "Hungarians Stage a Fast Over Rules for Voters." http://www.nytimes.com/2012/09/12/world/europe/hungarians-hold-hunger-strike-over-votingchanges.html?_r=0 (accessed 15 November 2012)

United Kingdom. Parliament. The Electoral Commission. Compulsory voting around the world Research report, 2006. 